\title{
Article \\ Characterizing Early-Season Nitrogen Fertilization Rate Effects on Growth, Yield, and Quality of Strawberry
}

\author{
Shinsuke Agehara
}

Citation: Agehara, S. Characterizing Early-Season Nitrogen Fertilization Rate Effects on Growth, Yield, and Quality of Strawberry. Agronomy 2021, 11, 905. https://doi.org/10.3390/ agronomy11050905

Academic Editor: Joji Muramoto

Received: 31 March 2021

Accepted: 3 May 2021

Published: 5 May 2021

Publisher's Note: MDPI stays neutral with regard to jurisdictional claims in published maps and institutional affiliations.

Copyright: (C) 2021 by the author. Licensee MDPI, Basel, Switzerland. This article is an open access article distributed under the terms and conditions of the Creative Commons Attribution (CC BY) license (https:/ / creativecommons.org/licenses/by/ $4.0 /)$.
Gulf Coast Research and Education Center, Institute of Food and Agricultural Sciences, University of Florida, 14625 CR 672, Wimauma, FL 33598, USA; sagehara@ufl.edu; Tel.: +1-813-419-6583

\begin{abstract}
In winter strawberry (Fragaria $\times$ ananassa Duch.) production, early-season nitrogen $(\mathrm{N})$ fertilization greatly affects fruit earliness and yields, especially when pre-plant $\mathrm{N}$ is not applied. The objective of this study was to characterize the dose-responses of canopy growth, yield, and fruit quality to early-season $\mathrm{N}$ fertilization in 'Florida Radiance' and 'Florida127' strawberry. Field experiments were conducted in west-central Florida, United States. Treatments included four $(0.56$, $0.84,1.12$ and $\left.1.40 \mathrm{~kg} \mathrm{ha}^{-1} \mathrm{~d}^{-1}\right)$ and five $\left(0.22,0.67,1.12,1.57\right.$, and $\left.2.02 \mathrm{~kg} \mathrm{ha}^{-1} \mathrm{~d}^{-1}\right)$ early-season $\mathrm{N}$ rates in the first and second growing seasons, respectively. Increasing the early-season $\mathrm{N}$ rate increased early and total season yields by up to $62 \%$ to $65 \%$ and $56 \%$ to $58 \%$, respectively, in the two cultivars. The total season yield had high positive correlations with leaf area and shoot DW. Model fitting analysis revealed cultivar-dependent dose-responses. Yield and berry size responses in 'Florida Radiance' were linear increases, whereas those in 'Florida127' were quadratic with peaks occurring at $\mathrm{N}$ rates of 1.21 or $1.57 \mathrm{~kg} \mathrm{ha}^{-1} \mathrm{~d}^{-1}$. In 'Florida Radiance', soluble solids concentration showed a linear dose-response with a slope of $-0.91\left(0.91^{\circ}\right.$ Brix decrease per $1 \mathrm{~kg} \mathrm{ha}^{-1} \mathrm{~d}^{-1} \mathrm{~N}$ increase $)$ during the early season. These results suggest that optimization of early-season $\mathrm{N}$ fertilization is an important production strategy to improve the profitability of winter strawberry production. Furthermore, fertilizer management that takes into account cultivar-dependent dose-responses can improve fertilizer use efficiency while minimizing fruit quality loss and environmental pollution risks.
\end{abstract}

Keywords: dose-response; fertility; fertilizer; Florida; Fragaria $\times$ ananassa; nutrient management

\section{Introduction}

Strawberry (Fragaria $\times$ ananassa Duch.) is one of the most important fruit crops in the world, and it is grown widely in temperate and subtropical climates. Global strawberry production was 8.89 million tons in 2019, a 41\% increase from 2010 [1]. In the United States, strawberry production in 2019 was 1.02 million tons on 18,130 ha [2]. California and Florida are the top strawberry-producing states, generating farmgate values of \$2214 and \$307 million, respectively [2]. In both states, strawberry is typically grown as an annual crop on raised beds covered with polyethylene mulch. Irrigation and fertilization are performed through one or two drip lines per bed, based on local growing conditions, soil types, and cultivar requirements [3].

Strawberry has a long harvest window, requiring frequent and intensive fertilization. Among mineral nutrients, nitrogen $(\mathrm{N})$ is generally the most limiting nutrient for crop production [4]. The range of $\mathrm{N}$ fertilization rates reported in literature for strawberries varies considerably among locations. In Argentina, for example, Gariglio et al. [5] reported that the yield of 'Chandler' strawberry increased with increasing $\mathrm{N}$ rate from 0 to $53 \mathrm{~kg} \mathrm{ha}^{-1}$ but showed no significant change at higher rates of 66 or $117 \mathrm{~kg} \mathrm{ha}^{-1}$. In Canada, Lamarre and Lareau [6] tested two $\mathrm{N}$ rates, 50 and $100 \mathrm{~kg} \mathrm{ha}^{-1}$, but found no significant response in the 'Tribute' strawberry. By contrast, Cárdenas-Navarro et al. [7] reported that $\mathrm{N}$ is often applied in excess of $600 \mathrm{~kg} \mathrm{ha}^{-1}$ in Mexico, which is 2.5 times as much as the regional recommended rate. Conflicting results are also reported for the effects of $\mathrm{N}$ fertilization on 
fruit quality, including firmness, fruit shape, size, soluble solids concentration (SSC), and titratable acidity [8].

In Florida, strawberry production occurs during the winter months, typically from mid-November through late March, under subtropical climate conditions. The soil in the strawberry production area is very sandy ( $>90 \%$ sand) with poor water and nutrient holding capacity [3]. Because of its high nutrient leaching potential, identifying optimum $\mathrm{N}$ fertilization rates is critical not only to improve crop productivity but also to minimize the risks of nitrate leaching and groundwater contamination. Therefore, previous research has focused on optimizing the fertilization program for the local growing conditions and cultivars. Hochmuth and Smajstrla [9] reported that daily, low-dose $\mathrm{N}$ application is critical to achieving high strawberry yields irrespective of N source. Santos and Chandler [3] reported that increasing the $\mathrm{N}$ rate from 0.5 to $0.9 \mathrm{~kg} \mathrm{ha}^{-1} \mathrm{~d}^{-1}$ increased the marketable yield of 'Strawberry Festival' but had no significant effect on the marketable yield of 'Winter Dawn'. The current fertilization recommendation developed based on these previous results is to apply pre-plant $\mathrm{N}$ of up to $45 \mathrm{~kg} \mathrm{ha}^{-1}$, followed by daily application through drip injection at 0.34 to $0.85 \mathrm{~kg} \mathrm{ha}^{-1} \mathrm{~d}^{-1}$, depending on the phenological stage [10]. However, some studies $[11,12]$ have shown little impact of pre-plant $\mathrm{N}$ fertilization on both early and total yields. Furthermore, many growers currently apply high $\mathrm{N}$ rates between 1.96 and $2.24 \mathrm{~kg} \mathrm{ha}^{-1} \mathrm{~d}^{-1}$ during the early season instead of applying pre-plant $\mathrm{N}$ [13]. When pre-plant $\mathrm{N}$ is not applied, the initial high-dose fertilization may be important for improving early canopy development and yield.

The discrepancy between the grower practices and the current recommendation must be addressed to promote more efficient nutrient management that contributes to sustainable crop production and environmental protection. It is also important to take into account cultivar-dependent nutrient requirements in fertilization recommendations. Therefore, the objective of this study was to characterize the dose-responses of canopy growth, yield, and fruit quality to early-season N fertilization in 'Florida Radiance' and 'Florida127' strawberry. These two cultivars are grown widely in Florida and other winter strawberry production regions $[14,15]$. This study also aimed to evaluate the long-term effects of early-season $\mathrm{N}$ fertilization on both yield and fruit quality.

\section{Materials and Methods}

\subsection{Experiment Site}

Strawberry field experiments were conducted at the University of Florida's Gulf Coast Research and Education Center in Balm, Florida, United States (latitude $27^{\circ} 76^{\prime}$; longitude $82^{\circ} 23^{\prime} \mathrm{W}$; elevation $39 \mathrm{~m}$ ), during the 2013-2014 and 2014-2015 growing seasons. The soil type at this study site is classified as Myakka fine sand (sandy, siliceous, Hyperthermic Oxyaquic Alorthods). The soil had a pH of 6.8 and organic matter content of $1.5 \%$.

\subsection{Plant Material}

Two major strawberry cultivars in Florida, 'Florida Radiance' and 'Florida127', were used in this study. Bare-root transplants of these two cultivars were shipped from a commercial nursery (G.W. Allen Nursery, Centreville, NS, Canada) to the study site and stored at $2{ }^{\circ} \mathrm{C}$ until transplanting. These transplants had 3-5 functional leaves.

\subsection{Field Preparation and Crop Management}

The raised beds used in this study were spaced $122 \mathrm{~cm}$ apart and measured $81 \mathrm{~cm}$ wide at the base, $71 \mathrm{~cm}$ wide at the shoulders, and $25 \mathrm{~cm}$ high at the bed top. During the bed preparation, beds were fumigated with PicClor 60 (TriEst Ag Group, Greenville, NC, USA) at $303 \mathrm{~kg} \mathrm{ha}^{-1}$ to control weeds, nematodes, and soil-borne diseases. The fumigant was delivered $20 \mathrm{~cm}$ deep using a standard fumigation rig with three knives per bed. Immediately after fumigation, one line of drip tubing $\left(0.95 \mathrm{~L} \mathrm{~h}^{-1}\right.$ emitter $^{-1}, 30.5-\mathrm{cm}$ emitter spacing) was installed $2.5 \mathrm{~cm}$ deep in the middle of each bed, and the beds were covered with black high-density polyethylene mulch (0.02-mm thick). 
Transplanting was performed by hand on 3 October 2013 and 9 October 2014 in the 2013-2014 and 2014-2015 growing seasons, respectively. Bare-root transplants were planted in double rows per bed spaced $30 \mathrm{~cm}$ apart with $38 \mathrm{~cm}$ between plants within each row. The planting density was 43,056 plants per hectare. Because bare-root transplants do not have active root systems, they require sprinkler irrigation to prevent desiccation until they are fully established [16]. Therefore, sprinkler irrigation was run during daylight hours $(9 \mathrm{~h}$ per day) for 12 and 13 days after transplanting in the 2013-2014 and 2014-2015 growing seasons, respectively. Thereafter, plants were watered daily by drip irrigation. The use of both sprinkler and drip irrigation is a standard practice used by strawberry growers in Florida [16]. Standard pest management practices used by local commercial strawberry growers were also followed.

\subsection{Fertilization Treatments}

Fertilization treatments tested in this study are described in Tables 1 and 2. Pre-plant $\mathrm{N}$ was not applied in both growing seasons. In the 2013-2014 growing season, treatments included four early-season $\mathrm{N}$ rates $\left(0.56,0.84,1.12\right.$, and $\left.1.40 \mathrm{~kg} \mathrm{ha}^{-1} \mathrm{~d}^{-1}\right)$ performed from 15 October to 14 December 2013 (Table 1). Thereafter, all treatments received the same $\mathrm{N}$ rate of $0.84 \mathrm{~kg} \mathrm{ha}^{-1} \mathrm{~d}^{-1}$. Total $\mathrm{N}$ inputs ranged from 91.3 to $142.5 \mathrm{~kg} \mathrm{ha}^{-1}$.

Table 1. Nitrogen (N) fertilization treatments tested for 'Florida Radiance' and 'Florida127' strawberry in the 2013-2014 growing season.

\begin{tabular}{|c|c|c|c|c|c|}
\hline \multirow{2}{*}{$\begin{array}{l}\text { Treatment } \\
\text { Number }\end{array}$} & \multicolumn{2}{|c|}{ Early-Season N Rate ${ }^{1}$} & \multicolumn{2}{|c|}{ Mid-Late Season N Rate ${ }^{2}$} & \multirow{2}{*}{$\begin{array}{c}\text { Total N Input } \\
\left(\mathrm{kg} \mathrm{ha}^{-1}\right)\end{array}$} \\
\hline & $\left(\mathrm{kg} \mathrm{ha}^{-1} \mathrm{~d}^{-1}\right)$ & $\left(\mathrm{kg} \mathrm{ha}^{-1}\right)$ & $\left(\mathrm{kg} \mathrm{ha}^{-1} \mathrm{~d}^{-1}\right)$ & $\left(\mathrm{kg} \mathrm{ha}^{-1}\right)$ & \\
\hline 1 & 0.56 & 34.2 & 0.84 & 57.1 & 91.3 \\
\hline 2 & 0.84 & 51.2 & 0.84 & 57.1 & 108.4 \\
\hline 3 & 1.12 & 68.3 & 0.84 & 57.1 & 125.4 \\
\hline 4 & 1.40 & 85.4 & 0.84 & 57.1 & 142.5 \\
\hline
\end{tabular}

${ }^{1}$ From 15 October to 14 December 2013. ${ }^{2}$ From 15 December 2013 to 20 February 2014.

Table 2. Nitrogen (N) fertilization treatments tested for 'Florida Radiance' and 'Florida127' strawberry in the 2014-2015 growing season.

\begin{tabular}{|c|c|c|c|c|c|}
\hline \multirow{2}{*}{$\begin{array}{c}\text { Treatment } \\
\text { Number }\end{array}$} & \multicolumn{2}{|c|}{ Early-Season N Rate ${ }^{1}$} & \multicolumn{2}{|c|}{ Mid-Late Season N Rate ${ }^{2}$} & \multirow{2}{*}{$\begin{array}{c}\text { Total N Input } \\
\left.\text { (kg ha }^{-1}\right)\end{array}$} \\
\hline & $\left(\mathrm{kg} \mathrm{ha}^{-1} \mathrm{~d}^{-1}\right)$ & $\left(\mathrm{kg} \mathrm{ha}^{-1}\right)$ & $\left(\mathrm{kg} \mathrm{ha}^{-1} \mathrm{~d}^{-1}\right)$ & $\left(\mathrm{kg} \mathrm{ha}^{-1}\right)$ & \\
\hline 1 & 0.22 & 11.9 & 1.12 & 82.9 & 94.8 \\
\hline 2 & 0.67 & 36.2 & 1.12 & 82.9 & 119.1 \\
\hline 3 & 1.12 & 60.5 & 1.12 & 82.9 & 143.4 \\
\hline 4 & 1.57 & 84.8 & 1.12 & 82.9 & 167.7 \\
\hline 5 & 2.02 & 109.1 & 1.12 & 82.9 & 192.0 \\
\hline
\end{tabular}

${ }^{1}$ From 22 October to 14 December 2014. ${ }^{2}$ From 15 December 2014 to 26 February 2015.

In the 2014-2015 growing season, treatments included five early-season $\mathrm{N}$ rates $(0.22$, $0.67,1.12,1.57$, and $2.02 \mathrm{~kg} \mathrm{ha}^{-1} \mathrm{~d}^{-1}$ ) performed from 22 October to 14 December 2014 (Table 2). Thereafter, all treatments received the same $\mathrm{N}$ rate of $1.12 \mathrm{~kg} \mathrm{ha}^{-1} \mathrm{~d}^{-1}$. Total $\mathrm{N}$ inputs ranged from 94.8 to $192.0 \mathrm{~kg} \mathrm{ha}^{-1}$.

In both growing seasons, urea ammonium nitrate $(32 \mathrm{~N}-0 \mathrm{P}-0 \mathrm{~K})$ was used for $\mathrm{N}$ fertilization. Other macro- and micro-nutrients were applied using a custom blend fertilizer that does not contain nitrogen $(0 \mathrm{~N}-0.9 \mathrm{P}-3.3 \mathrm{~K})$. Fertilization was performed daily through drip irrigation. Total phosphorous $(\mathrm{P})$ and potassium $(\mathrm{K})$ inputs were 16.3 and $59.6 \mathrm{~kg} \mathrm{ha}^{-1}$, respectively, in the 2013-2014 growing season, and 21.5 and $78.8 \mathrm{~kg} \mathrm{ha}^{-1}$, respectively, in the 2014-2015 growing season. 


\subsection{Plant Growth}

In the 2014-2015 growing season, two plants were sampled per replication on 14 January 2015 to determine mid-season growth responses to different $\mathrm{N}$ fertilization rates. Leaf area was measured using the LI-3100C Area Meter (LI-COR, Lincoln, NE, USA). The crown diameter was measured at the widest part using a digital caliper. Shoot and root dry weight were determined after drying samples at $65^{\circ} \mathrm{C}$ for at least $48 \mathrm{~h}$.

\subsection{Yield and Fruit Quality}

Strawberries were harvested twice a week from mid-November to late February in both seasons. November and December harvests were classified as the early season yield, and January and February harvests were classified as the late-season yield. Fruit grading was performed according to the U.S. Department of Agriculture grading standards [17]. Marketable berries included both U.S. No. 1 and No. 2 grades with a minimum weight of $10 \mathrm{~g}$. Other berries were graded as unmarketable. The number and weight of marketable and unmarketable berries were recorded.

In the 2014-15 growing season, four marketable berries were randomly selected per replication on 22 December 2014 and 9 February 2015. The juice was squeezed using a stainless-steel hand press juicer. Fruit SSC was measured using a digital refractometer (PAL-1; ATAGO, Tokyo, Japan) on unfiltered juice.

\subsection{Experimental Design and Statistical Analysis}

In both growing seasons, treatments were arranged in a split-plot design with earlyseason $\mathrm{N}$ treatment as the main plot factor and cultivar as the sub-plot factor. Each treatment had four plots (replicates), and each plot consisted of 20 plants.

To characterize the dose-responses of dependent variables to early-season $\mathrm{N}$ fertilization, curve fitting was performed using SigmaPlot (version 14.0; Systat Software, San Jose, CA, USA). Five models that are commonly used to describe growth and biological responses were fit to each data set: linear (1), quadratic (2), exponential plateau (3), exponential decay (4), and sigmoidal (5) models.

$$
\begin{gathered}
y=a+b x \\
y=a+b x+c x^{2} \\
y=a+b[1-\exp (-k x)] \\
y=a+b \exp (-k x) \\
y=a /\left[1+\exp -\left(x-x_{0}\right) / b\right]
\end{gathered}
$$

In Equations (1) and (2), $a$ is the $y$-intercept, $b$ is the linear coefficient, and $c$ is the quadratic coefficient. In Equation (3), a is the $y$-intercept, $b$ is the maximum increase in $y$, and $k$ is the rate constant. The sum of $a$ and $b$ is the upper asymptote, which represents the estimated maximum response of $y$. In Equation (4), $a$ is the lower asymptote, and $b$ is the maximum decrease in $y$. The sum of $a$ and $b$ represents $y$ when the early-season $\mathrm{N}$ rate is zero. In Equation (5), $a$ is the upper asymptote (estimated maximum value of $y$ ), $b$ is the rate constant, and $x_{0}$ represents the early-season $\mathrm{N}$ rate when $y$ reaches the midpoint between the baseline and maximum.

Model coefficients were deemed significant at $p \leq 0.05$. The best model was selected based on the smallest corrected Akaike information criterion. When the same model was selected for both cultivars, the model coefficients were compared between the two cultivars. The model coefficients were deemed significantly different between the two cultivars $(p \leq 0.05)$ if the $95 \%$ confidence intervals did not overlap.

To assess the linear correlation between mid-season growth variables and yield, linear regression was performed using SigmaPlot. The correlation was considered significant when the slope was significantly different from zero $(p \leq 0.05)$. 


\section{Results}

\subsection{Leaf Area Growth}

Mid-season leaf area growth showed different dose-responses to early-season $\mathrm{N}$ fertilization between the two cultivars (Figure 1). In 'Florida Radiance', increasing the early-season $\mathrm{N}$ fertilization rate increased leaf area by $78 \%$ (1121 to $1999 \mathrm{~cm}^{2}$ plant $\left.^{-1}\right)$ (Figure 1a). The dose-response was best described by a linear model with a slope of 448. In 'Florida127', increasing the early-season $\mathrm{N}$ fertilization rate increased leaf area by $45 \%$ (1495 to $2166 \mathrm{~cm}^{2}$ plant ${ }^{-1}$ ). The dose-response was best described by an exponential plateau model, with leaf area increasing more gradually at higher rates. According to this model, the estimated maximum leaf area was $2292 \mathrm{~cm}^{2}$ plant $^{-1}$. These dose-responses were also apparent in overhead canopy images (Figure 1b).
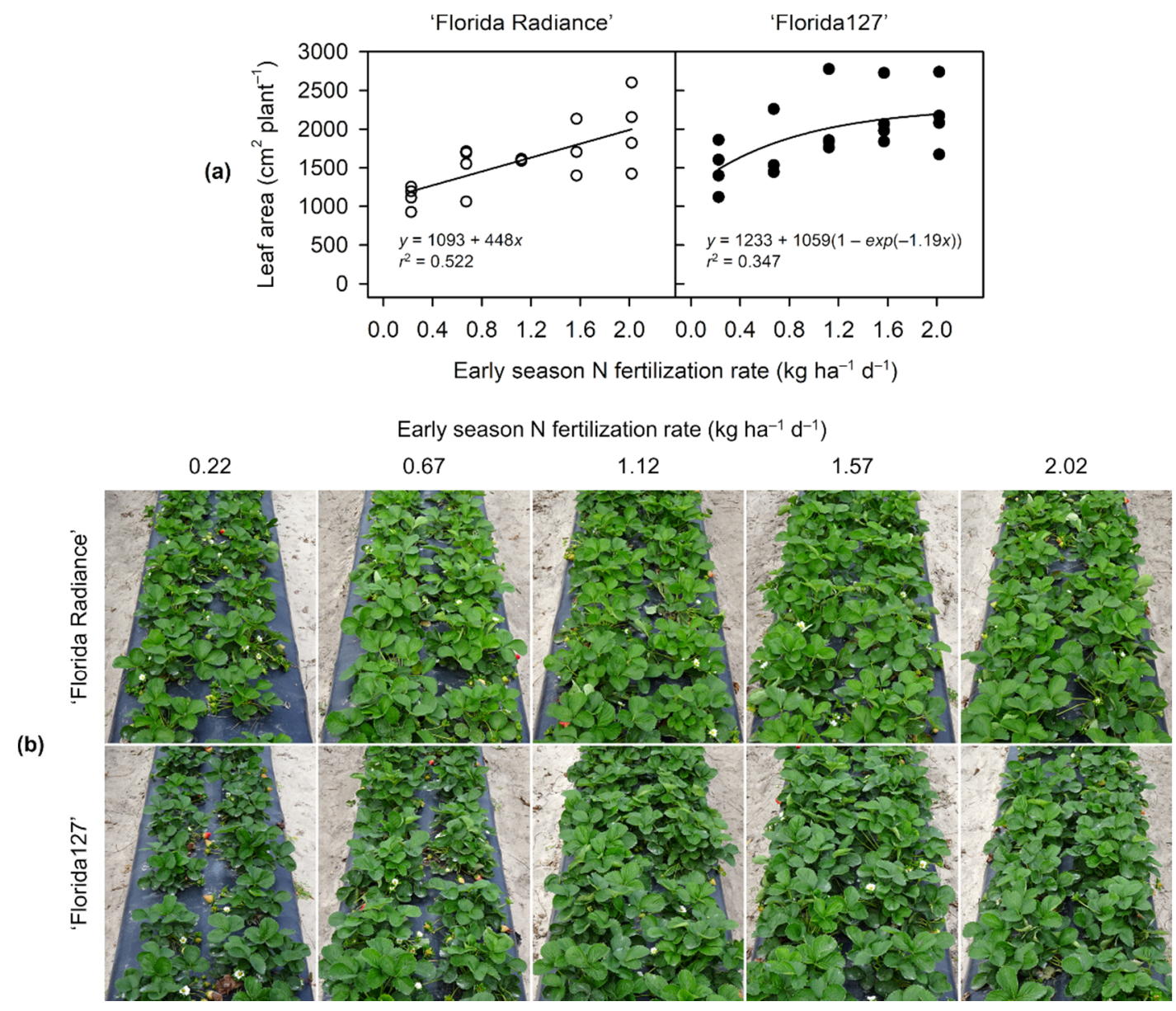

Figure 1. Leaf area growth responses of two strawberry cultivars to different early-season nitrogen (N) fertilization rates in the 2014-2015 growing season: (a) the best-fit model; (b) overhead canopy images. Leaf area data and images were collected on 13 January 2015. Treatments are as described in Table 2. Five models were fit to each data set: linear, quadratic, exponential plateau, exponential decay, and sigmoidal models. Only the significant $(p \leq 0.05)$ and best-fit model is shown for each data set.

\subsection{Marketable Yields}

Marketable yields showed different dose-responses to early-season $\mathrm{N}$ fertilization between the two cultivars (Figure 2). In the 2013-2014 growing season, increasing earlyseason $\mathrm{N}$ fertilization rate increased early, late, and total season marketable yields of 'Florida Radiance' by $60 \%$ (1.72 to $2.75 \mathrm{t} \mathrm{ha}^{-1}$ ), 25\% (7.63 to $9.53 \mathrm{t} \mathrm{ha}^{-1}$ ), and 31\% (9.35 to $12.29 \mathrm{t} \mathrm{ha}^{-1}$ ), respectively (Figure 2a). The dose-response was best described by a linear model throughout the growing season. The slope was highest for total season yield (3.03). In 'Florida127', by contrast, none of the tested models showed a significant fit. 
(a)

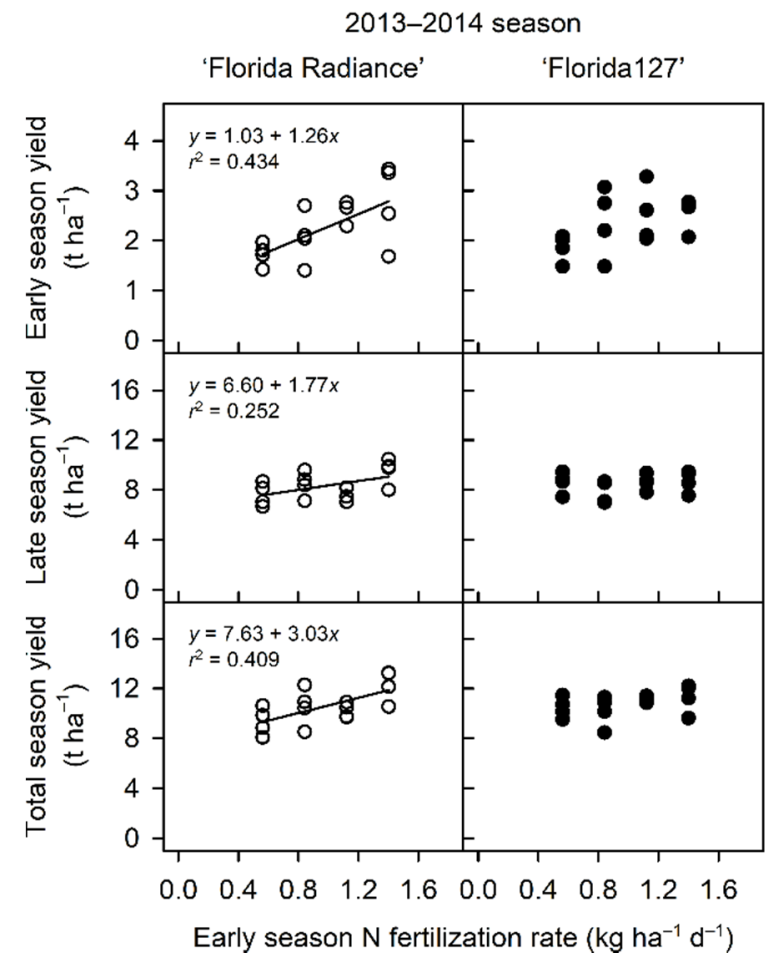

(b)

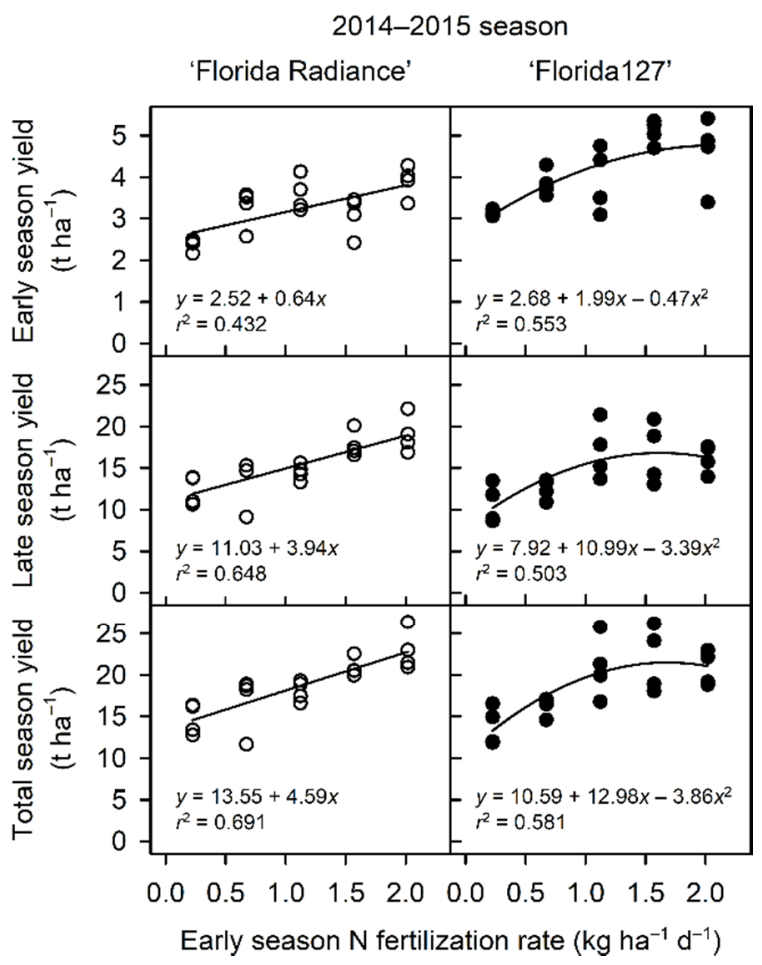

Figure 2. Marketable yield responses of two strawberry cultivars to different early-season nitrogen (N) fertilization rates: (a) 2013-2014 growing season (b) 2014-2015 growing season. Treatments are as described in Tables 1 and 2. Five models were fit to each data set: linear, quadratic, exponential plateau, exponential decay, and sigmoidal models. Only the significant $(p \leq 0.05)$ and best-fit model is shown for each data set. No regression line is shown when none of the models had a significant fit. Early season $=$ November-December. Late season = January-February.

In the 2014-2015 growing season, increasing early-season $\mathrm{N}$ fertilization rate increased early, late, and the total season marketable yields of 'Florida Radiance' by $65 \%$ (2.37 to $\left.3.90 \mathrm{t} \mathrm{ha}^{-1}\right)$, $55 \%\left(12.31\right.$ to $19.05 \mathrm{t} \mathrm{ha}^{-1}$ ), and $56 \%\left(14.68\right.$ to $\left.22.95 \mathrm{t} \mathrm{ha}^{-1}\right)$, respectively (Figure $\left.2 \mathrm{~b}\right)$. The dose-response was best described by a linear model throughout the growing season. The slope was highest for total season yield (4.59). In 'Florida127', increasing early-season $\mathrm{N}$ fertilization rate increased early, late, and total season marketable yields by $62 \%$ (3.13 to $\left.5.08 \mathrm{t} \mathrm{ha}^{-1}\right), 59 \%$ (10.69 to $17.02 \mathrm{t} \mathrm{ha}^{-1}$ ), and $58 \%$ (13.83 to $21.82 \mathrm{t} \mathrm{ha}^{-1}$ ), respectively. The dose-response was best described by a quadratic model, with yields increasing more gradually at higher $\mathrm{N}$ rates. The peak increase of early, late, and total season yields occurred at $\mathrm{N}$ rates of $1.57,1.12$, and $1.57 \mathrm{~kg} \mathrm{ha}^{-1} \mathrm{~d}^{-1}$, respectively. According to the quadratic equations, the maximum early, late, and total season marketable yields were 4.79, 16.83, and $21.50 \mathrm{tha}^{-1}$, respectively.

\subsection{Linear Correlations between Mid-season Growth Variables and Total Season Marketable Yield}

In both cultivars, total season yield was positively correlated with leaf area $\left(r^{2}=0.627-0.780\right)$ and the shoot DW $\left(r^{2}=0.398-0.826\right)$, but it had no significant correlation with the crown diameter and root DW (Figure 3). The slope of the regression line between leaf area and total season yield was similar between the two cultivars, whereas that between shoot DW and total season yield was significantly higher for 'Florida Radiance' than for 'Florida127' (0.98 vs. 0.50). 


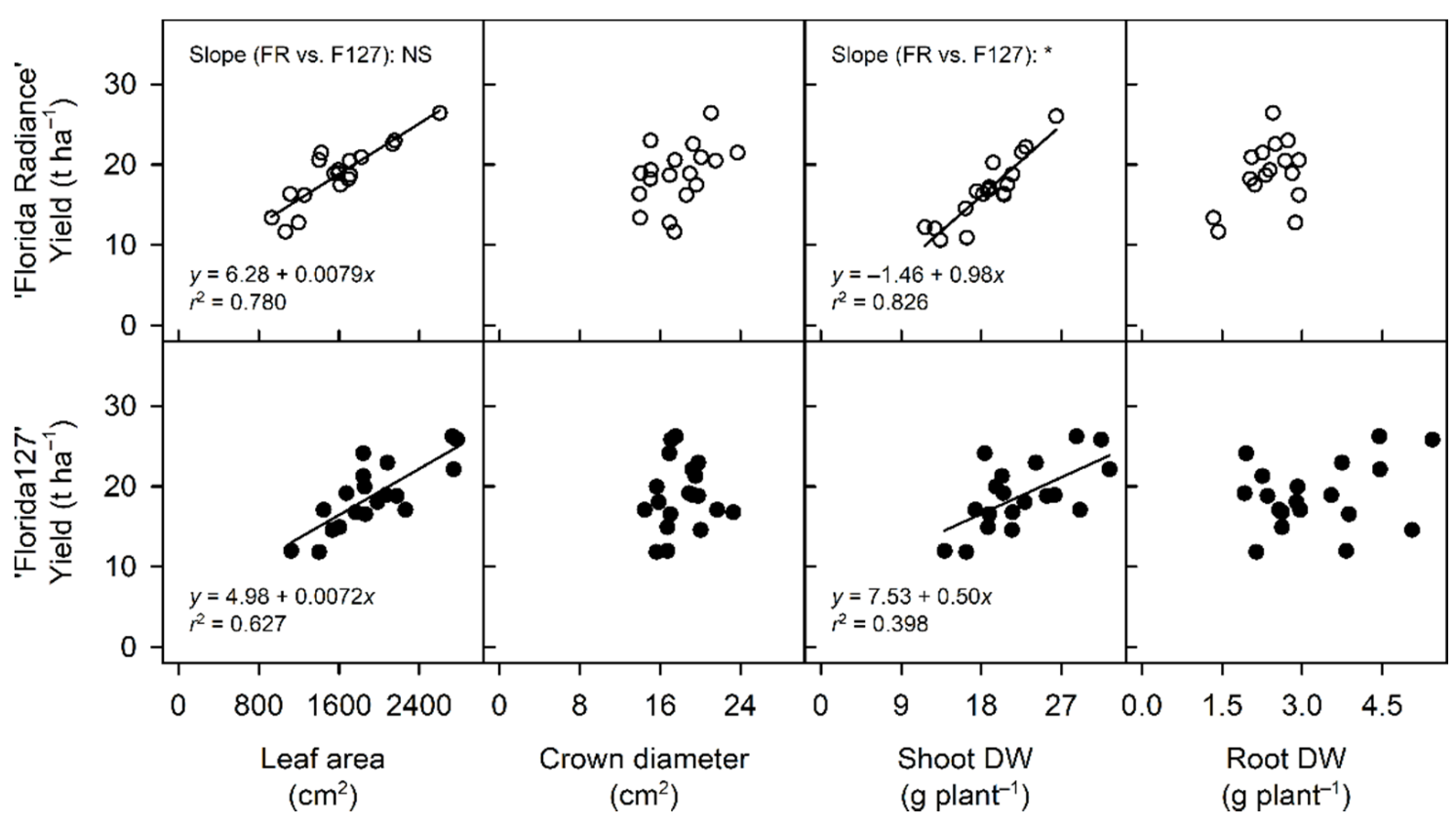

Figure 3. Linear regression between mid-season growth variables and the total season yield in two strawberry cultivars in the 2014-2015 growing season. Treatments are as described in Table 2. Plant growth data were collected on 13 January 2015. No regression line is shown when the correlation was non-significant $(p>0.05)$. When the linear correlation was significant for both cultivars, the slopes were compared between the two linear models using $95 \%$ confidence intervals. DW $=$ dry weight. FR = Florida Radiance. F127 = Florida127. NS = non-significant. ${ }^{*}=$ significant $(p \leq 0.05)$.

\subsection{Marketable and Unmarketable Yields}

Increasing the early-season $\mathrm{N}$ fertilization rate increased the percentage of marketable yield from $70.6 \%$ to $80.6 \%$ in 'Florida Radiance' and from $62.6 \%$ to $70.1 \%$ in 'Florida 127 ' (Figure 4). In both cultivars, the dose-response was best described by a linear model. There was no significant difference in the slopes between the two cultivars (5.06-5.97).

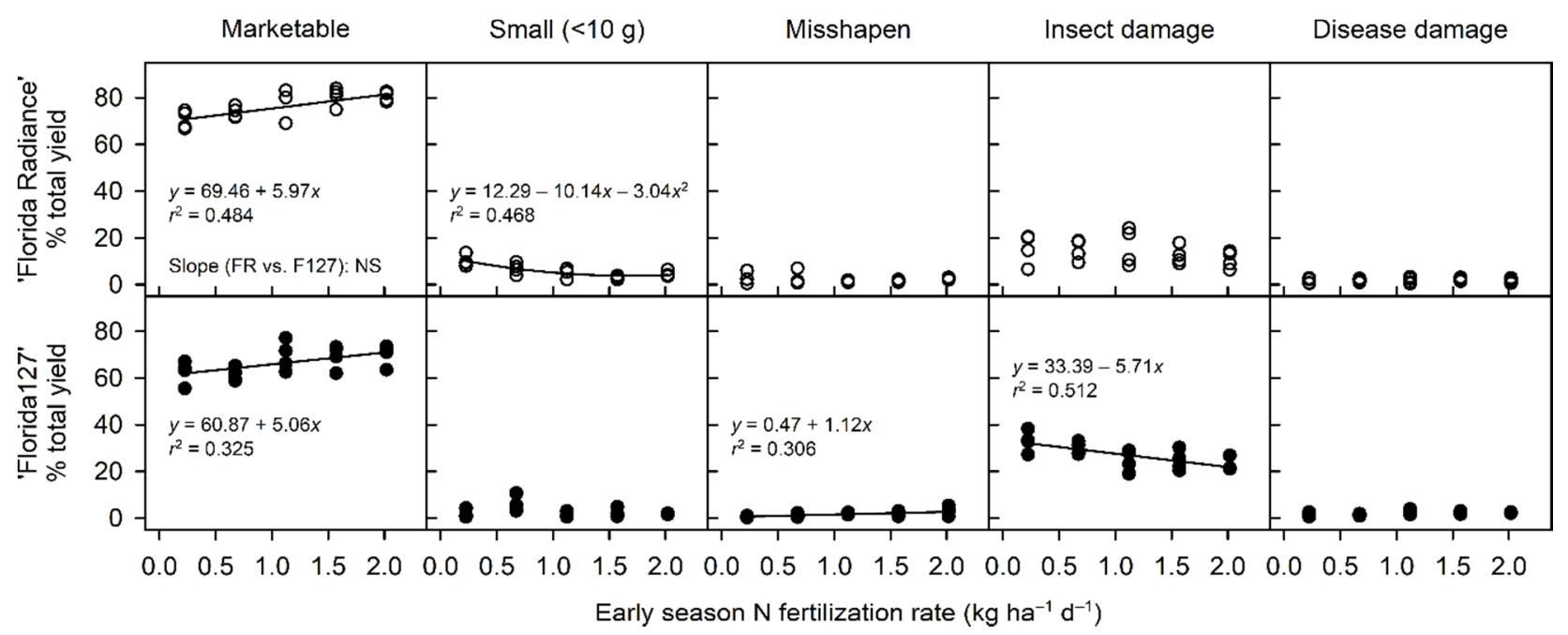

Figure 4. Marketable and unmarketable yield responses of two strawberry cultivars to different early-season nitrogen (N) fertilization rates in the 2014-2015 growing season. Treatments are as described in Table 2. Five models were fit to each data set: linear, quadratic, exponential plateau, exponential decay, and sigmoidal models. Only the significant $(p \leq 0.05)$ and best-fit model is shown for each data set. No regression line is shown when none of the models had a significant fit. FR $=$ Florida Radiance. F127 = Florida127. NS = non-significant. 
The percentage of unmarketable yields showed different dose-responses to earlyseason $\mathrm{N}$ fertilization between the two cultivars. Increasing the early-season $\mathrm{N}$ fertilization rate decreased the percentage of small fruit yield in 'Florida Radiance' from 10.0\% to $3.2 \%$. The dose-response was best described by a quadratic model with the maximum reduction occurring at an $\mathrm{N}$ rate of $1.57 \mathrm{~kg} \mathrm{ha}^{-1} \mathrm{~d}^{-1}$. None of the tested models showed a significant fit to other unmarketable yields.

In 'Florida127', increasing the early-season $\mathrm{N}$ fertilization rate increased the percentage of misshapen fruit yield from $0.6 \%$ to $3.2 \%$. The dose-response was best described by a linear model with a slope of 1.12. On the other hand, increasing the early-season $\mathrm{N}$ fertilization rate decreased the percentage of insect damage fruit yield from $32.9 \%$ to $22.7 \%$. The dose-response was best described by a linear model with a slope of -5.71 . None of the tested models showed a significant fit to other unmarketable yields.

\subsection{Average Berry Fresh Weight}

Average berry FW showed different dose-responses to early-season $\mathrm{N}$ fertilization between the two cultivars (Figure 5). In the 2013-2014 growing season, increasing the earlyseason $\mathrm{N}$ fertilization rate increased the late and total season average berry FW of 'Florida Radiance' by $9 \%$ (20.52 to $22.27 \mathrm{~g}$ ) and 6\% (19.15 to $20.32 \mathrm{~g}$ ), respectively (Figure $5 \mathrm{a}$ ). The dose-response was best described by a linear model. The slope was highest for late season yield (2.12). In 'Florida127', by contrast, none of the tested models showed a significant fit.

(a)

2013-2014 season

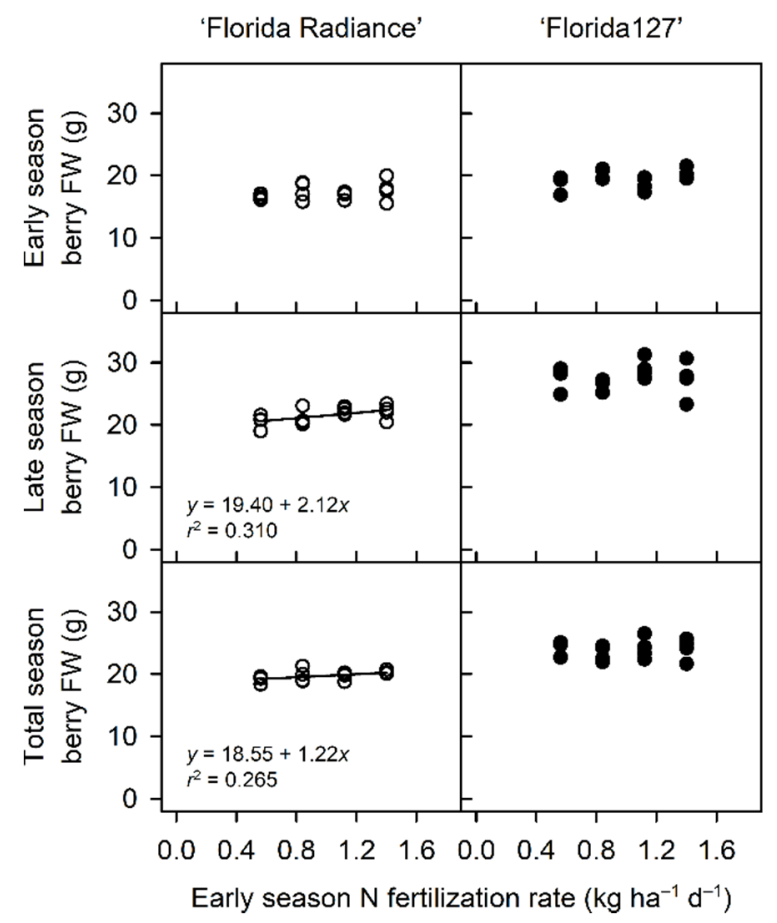

(b)

2014-2015 season

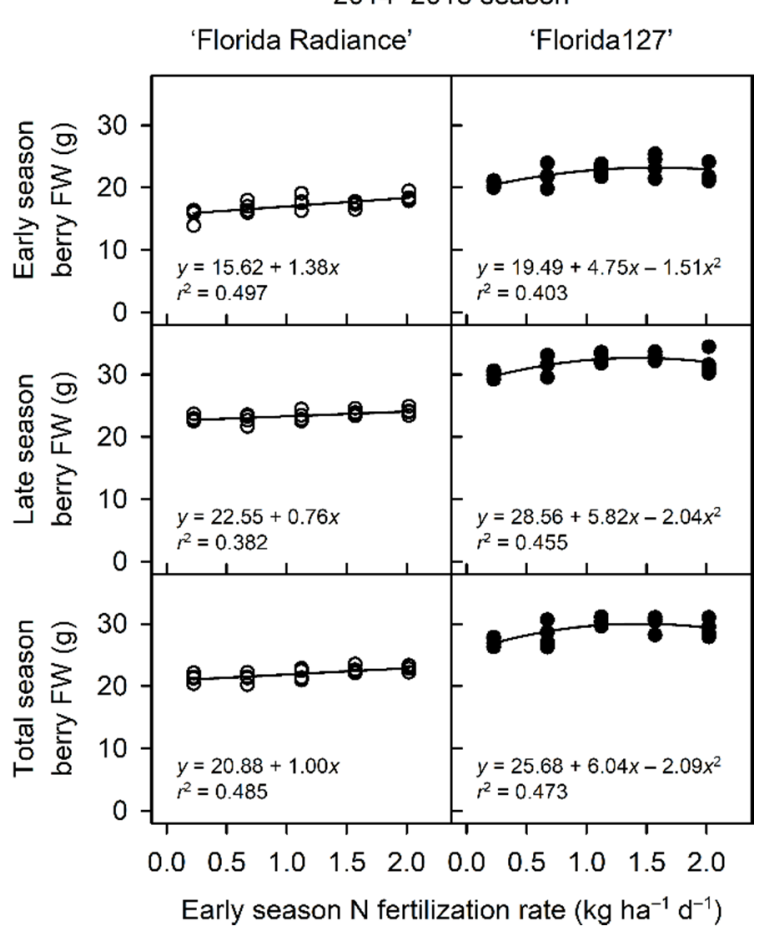

Figure 5. Average berry fresh weight (FW) responses of two strawberry cultivars to different early-season nitrogen (N) fertilization rates: (a) 2013-2014 growing season (b) 2014-2015 growing season. Treatments are as described in Tables 1 and 2. Five models were fit to each data set: linear, quadratic, exponential plateau, exponential decay, and sigmoidal models. Only the significant $(p \leq 0.05)$ and best-fit model is shown for each data set. No regression line is shown when none of the models had a significant fit. Early season = November-December. Late season = January-February.

In the 2014-2015 growing season, increasing early-season $\mathrm{N}$ fertilization rate increased the early, late, and total season average berry FW of 'Florida Radiance' by $18 \%$ (15.62 to $18.48 \mathrm{~g}$ ), $6 \%$ (22.77 to $24.10 \mathrm{~g}$ ), and $8 \%$ (21.30 to $22.90 \mathrm{~g}$ ), respectively (Figure $5 \mathrm{~b}$ ). The dose-response was best described by a linear model throughout the growing season. The 
slope was highest for the early season yield (1.38). In 'Florida127', increasing early-season $\mathrm{N}$ fertilization rate increased the average berry FW for early, late, and total season yields by $15 \%$ ( 20.58 to $23.60 \mathrm{~g}$ ), $10 \%$ ( 30.20 to $32.98 \mathrm{~g}$ ), and $11 \%$ (27.17 to $30.21 \mathrm{~g}$ ), respectively. The doseresponse was best described by a quadratic model, with berry FW increasing more gradually at higher $\mathrm{N}$ rates. The peak increase occurred at an $\mathrm{N}$ rate of $1.57 \mathrm{~kg} \mathrm{ha}^{-1} \mathrm{~d}^{-1}$ throughout the growing season. According to the quadratic equations, the maximum average berry $\mathrm{FW}$ for early, late, and total season yields was $23.25,32.71$, and $30.04 \mathrm{~g}$, respectively.

\subsection{Soluble Solids Concentration}

Increasing the early-season N fertilization rate decreased fruit SSC of 'Florida Radiance' by $14 \%$ (10.48 to $9.05^{\circ}$ Brix) during the early season (Figure 6$)$. The dose-response was best described by a linear model with a slope of -0.91 . In 'Florida 127 ', by contrast, none of the tested models showed a significant fit.

'Florida Radiance'

'Florida127'

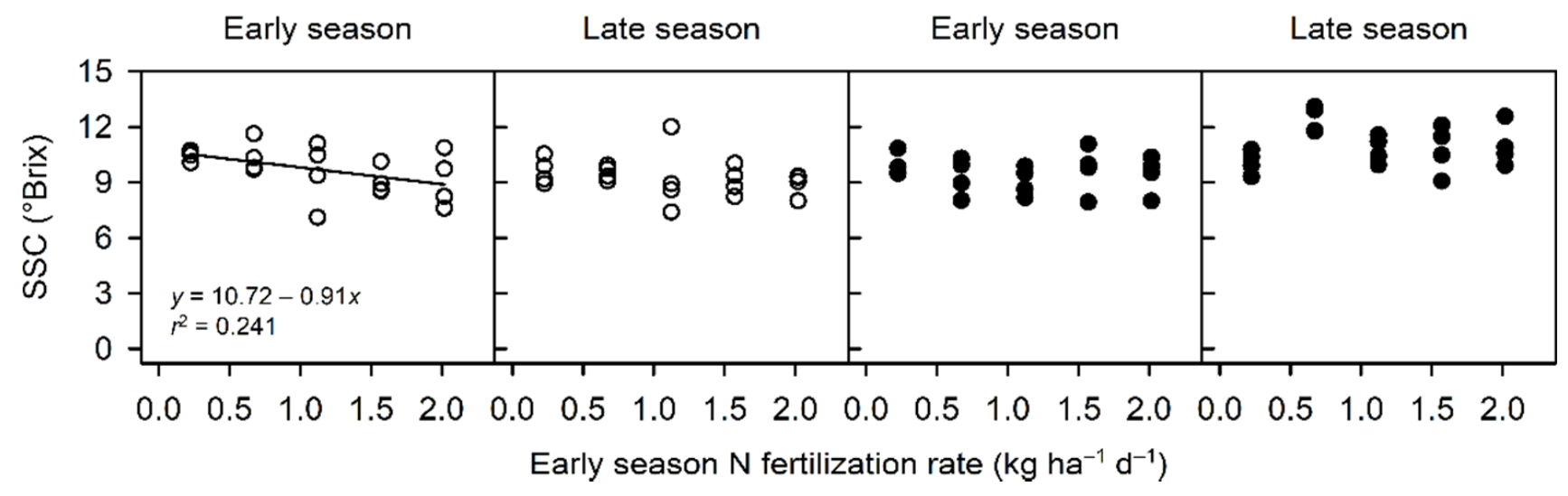

Figure 6. Fruit soluble solids concentration (SSC) responses of two strawberry cultivars to different early-season nitrogen (N) fertilization rates in the 2014-2015 growing season. Treatments are as described in Table 2. Five models were fit to each data set: linear, quadratic, exponential plateau, exponential decay, and sigmoidal models. Only the significant $(p \leq 0.05)$ and best-fit model is shown for each data set. No regression line is shown when none of the models had a significant fit. Early season $=$ November-December. Late season $=$ January-February.

\section{Discussion}

\subsection{Preferential Allocation of N to Canopy Growth Promotes Yield Increases by Early-Season $N$ Fertilization}

The optimum canopy growth is critical to support strawberry fruit production [18]. Early canopy growth promotion is particularly important to increase early-season yield in winter strawberry production. Under subtropical climate conditions, the growth of strawberry plants is often inhibited by heat stress during establishment [18,19]. Deschamps et al. [18] reported that, compared to black plastic mulch, cooling effects of white-striped plastic mulch resulted in average increases of $11 \%$ and $31 \%$ in early season canopy area and yield, respectively, in two strawberry cultivars. In this study, increasing the early-season $\mathrm{N}$ fertilization rate increased mid-season leaf area by up to $78 \%$ and $45 \%$ in 'Florida Radiance' and 'Florida127', respectively. Furthermore, among four shoot and root growth variables, leaf area and shoot DW had high positive correlations with total season yield, suggesting that early canopy growth promotion contributes to high strawberry yields. Increasing the leaf area during establishment may also help lessen heat stress by increasing transpiration capacity and leaf cooling [4].

Interestingly, root DW was not significantly affected by the early-season $\mathrm{N}$ rate, and it had no significant correlation with the total season yield. These results suggest that strawberry plants grown under subtropical climate conditions preferentially allocate more 
$\mathrm{N}$ toward shoot growth rather than root growth. In future research, it would be interesting to investigate if this $\mathrm{N}$ allocation pattern varies between different climates.

\subsection{Early-Season N Fertilization Has Long-Term Effects on Yield}

The nutrient demand of strawberry plants increases over the growing season as they develop larger and denser canopies and produce more berries. In Florida, however, strawberry growers often apply $\mathrm{N}$ at high rates (1.96-2.24 $\left.\mathrm{kg} \mathrm{ha}^{-1} \mathrm{~d}^{-1}\right)$ during the early season and then gradually switch to lower rates [13]. When pre-plant $\mathrm{N}$ is not applied, the initial high-dose fertilization may be important for improving early canopy development and yield in winter strawberry production. The results in this study confirm these beneficial effects of early-season $\mathrm{N}$ fertilization. This observation is interesting, especially when considering the relatively low nutrient demand during the early season. The unique root morphology of strawberry bare-root transplants may explain this interesting observation. Bare-root transplants are shipped in boxes from nurseries to strawberry production farms after cleaning the soil from the roots [20]. As a result, most of the transplants' roots become desiccated before transplanting. Since the initial nutrient uptake capacity of bareroot transplants is extremely limited [20], it is likely that high concentrations of fertilizer solution applied to the root zone improves the nutrient uptake by the transplants until sufficient new root development occurs.

The results in this study also demonstrate that optimum early-season $\mathrm{N}$ fertilization can increase not only early season yield but also late season yield. The leaf area is an important plant trait that directly affects the capacity of photosynthesis, biomass accumulation, and ultimately fruit production $[4,21]$. The long-term effects of early-season $\mathrm{N}$ fertilization may be associated with the early establishment of more productive canopy size and structure.

\subsection{Dose-Responses of Yield and Fruit Quality to Early-Season N Fertilization Are Cultivar-Dependent}

Growth and fruiting characteristics, such as canopy size and structure, berry size, yield, seasonal yield distribution, and fruit quality, vary considerably among strawberry cultivars [22]. For example, 'Florida Radiance' is characterized by its moderately compact canopy, low to medium vigor, very long pedicels, high early and late season yields, large, long-conic berries, and moderate SSC [14,22]. 'Florida127' is characterized by its moderately compact and robust canopy, upright and long pedicels, high early and late season yields, very large, conic to broad-conic berries, and high SSC [15]. It is documented that they have similar yields, but 'Florida127' produces larger berries with higher SSC than 'Florida Radiance' [15]. These characteristics of the two cultivars were also observed in this study.

Model fitting analysis used in this study clearly demonstrates that dose-responses of yield and fruit quality to early-season $\mathrm{N}$ fertilization are cultivar-dependent. In 'Florida Radiance', linear yield increases with slopes of up to 4.59 (4.59 $\mathrm{t} \mathrm{ha}^{-1}$ yield increase per $1 \mathrm{~kg} \mathrm{ha}^{-1} \mathrm{~d}^{-1} \mathrm{~N}$ increase) indicates its high $\mathrm{N}$ demand and high responsiveness to $\mathrm{N}$ fertilization. The average berry size also showed linear increases with slopes of up to 2.12 (2.12 $\mathrm{g}$ increase per $1 \mathrm{~kg} \mathrm{ha}^{-1} \mathrm{~d}^{-1} \mathrm{~N}$ increase). The absence of plateau in these response curves suggests that yield and berry size could be further increased by adding more $\mathrm{N}$ than the highest rate used in this study. By contrast, the yield and berry FW of 'Florida127' showed quadratic dose-responses with peaks occurring at $\mathrm{N}$ rates of 1.21 or $1.57 \mathrm{~kg} \mathrm{ha}^{-1} \mathrm{~d}^{-1}$, suggesting that this cultivar has a lower $\mathrm{N}$ demand than 'Florida Radiance'.

'Florida Radiance' is known to be susceptible to heat stress during establishment because of its compact canopy and low vigor $[14,22]$. The leaf area plays important roles not only in water and nutrient uptake but also in leaf cooling [4]. Therefore, the high responsiveness of this cultivar to $\mathrm{N}$ fertilization may be explained by the dual effects of canopy growth promotion on improving $\mathrm{N}$ uptake and alleviating heat stress.

The percentage of marketable yield showed similar linear increases with increasing early-season $\mathrm{N}$ fertilization rate in both cultivars. The improved fruit marketability in 
'Florida Radiance' was due to reductions in small fruit yield, whereas that in 'Florida127' was due to reductions in insect damage fruit yield. Insect damage was caused mainly by thrips. It can be speculated that increased canopy size or density may have reduced the infestation of thrips on flowers or berries. Therefore, optimum $\mathrm{N}$ fertilization may increase strawberry yield not only by promoting more productive canopy growth but also by creating conditions that are more tolerant to insect pests.

It is important to note that, for 'Florida127', the percentage of misshapen fruit yield showed a positive linear response to the early-season $\mathrm{N}$ rate. Although the slope in the linear model indicates that the increase was relatively small $\left(1.12 \%\right.$ increase per $1 \mathrm{~kg} \mathrm{ha}^{-1} \mathrm{~d}^{-1}$ $\mathrm{N}$ increase), misshapen fruit is a practical issue that requires attention for this high-value crop, in which visual fruit quality is of great importance. Misshapen fruit is often associated with boron and calcium deficiencies [23]. Increased fruit yield may have increased nutrient demand by plants, thereby inducing deficiencies of boron or calcium and thus increasing the incidence of misshapen fruit. To minimize the negative side effect of increasing $\mathrm{N}$ fertilization rate, it may be necessary to optimize the fertilization of other nutrients.

For strawberry fruit, SSC is an important quality attribute, and it is often associated with favorable sensory ratings in taste panel evaluations [24,25]. In this study, SSC of 'Florida Radiance' showed a linear dose-response with a slope of $-0.91\left(0.91^{\circ}\right.$ Brix decrease per $1 \mathrm{~kg} \mathrm{ha}^{-1} \mathrm{~d}^{-1} \mathrm{~N}$ increase) during the early season. Approximately $80 \%$ to $90 \%$ of SSC in strawberries consists of sugars [26]. The reduction in SSC could be due to the partitioning of sugars into more berries or the dilution of sugars caused by fruit enlargement [27]. However, no significant dose-response was observed in SSC of 'Florida Radiance' during the late season or SSC of 'Florida127' throughout the growing season.

\section{Conclusions}

In this study, increasing the early-season $\mathrm{N}$ fertilization rate increased the marketable yield of 'Florida Radiance' and 'Florida127' by $62 \%$ to $65 \%$ in November and December, during which strawberry prices are typically highest [28]. Although the plant growth assessment was performed only in the 2014-2015 season, high correlations of mid-season canopy growth variables with total season yield indicate the importance of establishing a productive canopy during the early season. Therefore, optimization of early-season $\mathrm{N}$ fertilization appears to be an important production strategy to improve the profitability of winter strawberry production.

Furthermore, fertilizer management that takes into account cultivar-dependent doseresponses can improve fertilizer use efficiency while minimizing fruit quality loss and environmental pollution risks. The model-fitting analysis demonstrates that 'Florida Radiance' is more responsive to early-season $\mathrm{N}$ fertilization than 'Florida127' in terms of both yield and fruit quality. The optimum $\mathrm{N}$ rate must be determined based on the relative importance of yield and fruit quality in the local market. For 'Florida127', by contrast, yield can be maximized at the early-season $\mathrm{N}$ rate of $1.57 \mathrm{~kg} \mathrm{ha}^{-1} \mathrm{~d}^{-1}$ with no negative impact on fruit quality. Further research is needed to examine the effects of $\mathrm{N}$ fertilization on various fruit quality attributes over multiple seasons.

Funding: This research was funded by the Florida Strawberry Research and Education Foundation. Institutional Review Board Statement: Not applicable.

Informed Consent Statement: Not applicable.

Data Availability Statement: The data presented in this study are available on request from the corresponding author.

Acknowledgments: I thank all members of the Horticultural Crop Physiology Lab at the Gulf Coast Research and Education Center for their technical assistance.

Conflicts of Interest: The author declares no conflict of interest. 


\section{References}

1. Food and Agriculture Organization of the United Nations. Available online: http://www.fao.org/faostat/en/\#data/QC (accessed on 27 February 2021).

2. U.S. Department of Agriculture. Available online: https:/ / quickstats.nass.usda.gov/ (accessed on 13 April 2021).

3. Santos, B.M.; Chandler, C.K. Influence of nitrogen fertilization rates on the performance of strawberry cultivars. Int. J. Fruit Sci. 2009, 9, 126-135. [CrossRef]

4. Taiz, L.; Zeiger, E. Plant Physiology, 5th ed.; Sinauer Associates: Sunderland, MD, USA, 2010.

5. Gariglio, N.F.; Pilatti, R.A.; Baldi, B.L. Using nitrogen balance to calculate fertilization in strawberries. HortTechnology 2000, 10, 147-150. [CrossRef]

6. Lamarre, M.; Lareau, M. Influence of nitrogen, potassium and magnesium fertilization on day-neutral strawberries in Quebec. Acta Hortic. 1996, 439, 701-704. [CrossRef]

7. Cárdenas-Navarro, R.; López-Pérez, L.; Lobit, P.; Escalante-Linares, O.; Castellanos-Morales, V.; Ruíz-Corro, R. Diagnosis of N status in strawberry (Fragaria $\times$ ananassas Duch). Acta Hortic. 2003, 654, 257-262. [CrossRef]

8. Nestby, R.; Lieten, F.; Pivot, D.; Lacroix, C.R.; Tagliavini, M. Influence of mineral nutrients on strawberry fruit quality and their accumulation in plant organs. A review. Acta Hortic. 2004, 649, 201-206. [CrossRef]

9. Hochmuth, G.J.; Smajstrla, A.G. Fertilizer Application and Management for Micro (Drip)-Irrigated Vegetables in Florida; University of Florida, Cooperative Extension Service, Institute of Food and Agricultural Sciences: Gainesville, FL, USA, 1991.

10. Liu, G.; Simonne, E.H.; Morgan, K.T.; Hochmuth, G.J.; Agehara, S.; Mylavarapu, R.; Dittmar, P.J. 2020-2021 Vegetable production handbook: Chapter 2. Fertilizer management for vegetable production in Florida. EDIS 2020. [CrossRef]

11. Agehara, S.; Santos, B.M.; Whidden, A.J. Nitrogen fertilization of strawberry cultivars: Is preplant starter fertilizer needed? EDIS 2017, 1-4.

12. Albregts, E.E.; Clark, G.A.; Stanley, C.D.; Zazueta, F.S.; Smajstrla, A.G. Preplant fertilization of fruiting microirrigated strawberry. HortScience 1991, 26, 1176-1177. [CrossRef]

13. Shahzad, S.; Silvasy, T.; Agehara, S. Optimization of early-season nitrogen fertilization program for new strawberry cultivar 'Florida Beauty'. Proc. Fla. State Hortic. Soc. 2018, 131, 103-105.

14. Whitaker, V.M.; Chandler, C.K.; Santos, B.M.; Peres, N.A. 'Florida Radiance' strawberry. EDIS 2013, 6, 1-4. [CrossRef]

15. Whitaker, V.M.; Chandler, C.K.; Peres, N.A. Sensation ${ }^{\mathrm{TM}}$ brand 'Florida127' strawberry. EDIS 2014, 1-4. [CrossRef]

16. Torres-Quezada, E.; Zotarelli, L.; Whitaker, V.M.; Agehara, S. Methods for strawberry transplant establishment in Florida. EDIS 2020, 6, 1-4. [CrossRef]

17. U.S. Department of Agriculture. United States Standards for Grades of Strawberries. 2006. Available online: https://www.ams. usda.gov/sites/default/files/media/Strawberry_Standard\%5B1\%5D.pdf (accessed on 27 February 2021).

18. Deschamps, S.S.; Whitaker, V.M.; Agehara, S. White-striped plastic mulch reduces root-zone temperatures during establishment and increases early season yields of annual winter strawberry. Sci. Hortic. 2019, 243, 602-608. [CrossRef]

19. Deschamps, S.S.; Agehara, S. Metalized-striped plastic mulch reduces root-zone temperatures during establishment and increases early-season yields of annual winter strawberry. HortScience 2019, 54, 110-116. [CrossRef]

20. Sangha, B.; Agehara, S. Using a scanner-based rhizotron system to characterize root morphological responses of bare-root strawberry transplants to nitrogen fertilization rates. Proc. Fla. State Hortic. Soc. 2017, 130, 129-132.

21. Amthor, J.S. Improving photosynthesis and yield potential. In Improvement of Crop Plants for Industrial End Uses; Ranalli, P., Ed.; Springer: Dordrecht, The Netherlands, 2007; pp. 27-58.

22. Whitaker, V.M.; Santos, B.M.; Peres, N.A. University of Florida strawberry cultivars. EDIS 2012, 4, 1-4.

23. Carew, J.G.; Morretini, M.; Battey, N.H. Misshapen fruits in strawberry. Small Fruits Rev. 2003, 2, 37-50. [CrossRef]

24. Jouquand, C.; Chandler, C.; Plotto, A.; Goodner, K. A sensory and chemical analysis of fresh strawberries over harvest dates and seasons reveals factors that affect eating quality. J. Amer. Soc. Hortic. Sci. 2008, 133, 859-867. [CrossRef]

25. Wozniak, W.; Radajewska, B.; Reszelska-Sieciechowicz, A.; Dejwor, I. Sugars and acid content influence organoleptic evaluation of fruits of six strawberry cultivars from controlled cultivation. Acta Hortic. 1997, 439, 333-336. [CrossRef]

26. Perkins-Veazie, P. Growth and ripening of strawberry fruit. In Horticultural Reviews; Janick, J., Ed.; Wiley: Hoboken, NJ, USA, 1995; pp. 267-297.

27. Davis, D.R. Declining fruit and vegetable nutrient composition: What is the evidence? HortScience 2009, 44, 15-19. [CrossRef]

28. Wu, F.; Guan, Z.; Whitaker, V. Florida strawberry growers need more early yield to improve profitability. EDIS 2017, 2, 1-3. [CrossRef] 